\title{
Substitusi Media Murashige dan Skoog/MS dengan Air Kelapa dan Pupuk Daun Majemuk pada Pertumbuhan Anggrek Dendrobium secara in vitro (In Vitro Growth of Dendrobium Orchids under Substitution Murashige dan Skoog/MS Medium With Coconut Water and Compound Leaf Fertilizer)
}

\author{
Annatje E.B. Inkiriwang ${ }^{1)^{*}}$, Jeany Mandang ${ }^{1)}$ dan Semuel Runtunuwu1) \\ 1)Program Studi Agronomi, Pasca Sarjana Universitas Sam Ratulangi, Kampus UNSRAT \\ Manado 95115 \\ Email korespondensi: a_inkiriwang@yahoo.com
}

Diterima 3 Februari 2016, diterima untuk dipublikasikan 29 Februari 2016

\begin{abstract}
Abstrak
Penelitian ini bertujuan untuk menentukan konsentrasi substitusi air kelapa dan pupuk daun majemuk yang tepat pada media MS terhadap pertumbuhan anggrek Dendrobium secara in vitro. Penelitian ini menggunakan Rancangan Acak Lengkap (RAL) dengan 7 perlakuan dan 10 kali ulangan. Variabel yang diamati adalah persentase eksplan yang bertunas, jumlah tunas, jumlah daun, tinggi tanaman dan jumlah akar. Hasil penelitian menunjukkan substitusi media MS $50 \%$, air kelapa $30 \%$ dan pupuk daun majemuk (Growmore®) 1,5 g/L menghasilkan rata-rata persentase eksplan yang bertunas sebesar 6,78 \%; jumlah tunas sebesar 1,26 dan tinggi tanaman sebesar 1,20 cm.

Kata kunci: air kelapa, in vitro, media MS, pupuk daun majemuk
\end{abstract}

\section{Abstract}

This research was aimed to determine the proper concentration of substitution of coconut water and compound leaf fertilizer in Murashige dan Skoog (MS) medium on the in vitro growth of Dendrobium orchids. The completely randomized design experiment consisted of 7 treatments and 10 replicates. The measured parameters were the percentage of sprouted explants, number of shoots, number of leaves, plant height and number of roots. The result showed that the substitution of $50 \%$ media MS, $30 \%$ coconut water and $1.5 \mathrm{~g} / \mathrm{L}$ leaf fertilizer (Growmore ${ }^{\circledR}$ ) resulted the growth of shoot explant as much as $6.78 \%$ the shoot number of 1.26 and $1.20 \mathrm{~cm}$ plant height .

Keywords: coconut water, compound leaf fertilizer, in vitro, MS medium

\section{PENDAHULUAN}

Tanaman anggrek termasuk tanaman hias yang mempunyai nilai keindahan pada bunganya, bahkan anggrek merupakan salah satu kekayaan hayati Indonesia. Tanaman ini memiliki nilai ekonomis yang tinggi karena bentuknya unik, warnanya menarik dan daya tahannya lebih lama dari pada bunga potong komersial lainnya seperti mawar, anyelir dan gladiol. Keunikan karakternya menjadikan kehadiran anggrek di dalam suatu rangkaian bunga potong sulit digantikan oleh bunga lain (Iswanto 2010).

Pengembangan anggrek di Indonesia masih relatif lambat. Rendahnya produksi akibat penggunaan bibit yang kurang bermutu merupakan salah satu penyebabnya. Untuk mengatasi masalah penyediaan 
bibit bermutu dan dalam skala besar perlu dilakukan teknik perbanyakan secara tepat dan efisien. Penggunaan kultur in vitro merupakan salah satu alternatif yang dapat dilakukan. Kultur in vitro dapat menghasilkan bibit tanaman dalam skala besar dan seragam dengan waktu yang relatif singkat.

Salah satu faktor penentu keberhasilan dalam perbanyakan tanaman melalui kultur in vitro adalah media yang digunakan. Media kultur jaringan tidak hanya menyediakan unsur-unsur hara makro dan mikro tetapi juga gula, vitamin dan zat pengatur tumbuh. Berbagai komposisi media kultur in vitro telah diformulasikan untuk mengoptimalkan pertumbuhan dan perkembangan tanaman yang dikulturkan.

Media kultur in vitro yang sering digunakan untuk perbanyakan tanaman anggrek adalah media MS (Murashige dan Skoog). Media ini mengandung unsur hara makro dan unsur mikro seperti myoinositol, niacin, pyridoxin $\mathrm{HCl}$, thiamin $\mathrm{HCl}$, glycine dan glukosa (Gunawan 1987). Air kelapa mengandung komponenkomponen yang dibutuhkan dalam pertumbuhan tanaman kultur in vitro. Bahan organik yang dikandung air kelapa hampir sama seperti pada media MS, yaitu gula, gula alkohol, asam amino, asam organik, vitamin dan fitohormon (Mandang 1995). Modifikasi media kultur in vitro menggunakan pupuk daun majemuk yaitu growmore ${ }^{\circledR}$ sebagai media dasar dan air kelapa digunakan dalam penelitian ini. Pupuk daun majemuk growmore ${ }^{\circledR}$ mengandung unsur-unsur makro seperti $\mathrm{N} 32 \%, \mathrm{P}_{2} \mathrm{O}_{5} 10 \%, \mathrm{~K}_{2} \mathrm{O}$ $10 \%$ dan unsur-unsur mikro seperti $\mathrm{Ca}$ 0,05\%, Mg 0,10\%, S 0,20\%, B 0,03\%,
Cu 0,05\% sehingga diharapkan dapat mensubstitusi kebutuhan unsur hara makro dan mikro yang terkandung dalam media MS serta air kelapa diharapkan dapat mensubstitusi kebutuhan vitamin dalam media MS.

Berdasarkan uraian di atas, maka perlu diadakan penelitian tentang substitusi media MS dengan air kelapa dan pupuk daun majemuk terhadap pertumbuhan anggrek Dendrobium secara in vitro. Penelitian ini bertujuan untuk menentukan konsentrasi substitusi air kelapa dan pupuk daun majemuk yang tepat pada media MS terhadap pertumbuhan anggrek Dendrobium secara in vitro.

\section{METODE}

Penelitian dilaksanakan di Laboratorium Bioteknologi Jurusan Budidaya Fakultas Pertanian Universitas Sam Ratulangi Manado dari bulan Mei sampai Agustus 2012. Penelitian ini menggunakan Rancangan Acak Lengkap (RAL) yang terdiri dari 7 perlakuan dan 10 kali ulangan, sehingga terdapat 70 satuan percobaan (Tabel 1). Tiap satuan percobaan terdiri dari 2 botol kultur dengan 2 tunas setiap botol sehingga terdapat 140 botol dan 280 tunas. Variabel yang diamati dalam penelitian ini ialah persentase eksplan yang bertunas, jumlah tunas, jumlah daun, tinggi tanaman dan jumlah akar. Data yang hasil pengamatan dianalisis dengan analisis sidik ragam dan apabila berbeda nyata, maka dilanjutkan dengan uji Beda Nyata Terkecil (BNT). Prosedur kerja mengikuti tahap sterilisasi alat, pembuatan media sesuai perlakuan (A, B, C, D,E, F dan G), penanaman eksplan dan pemeliharaan kultur. 
Tabel 1. Variasi Perlakuan dalam penelitian

\begin{tabular}{cccc}
\hline & \multicolumn{3}{c}{ Komposisi Media } \\
\cline { 2 - 4 } Perlakuan & MS $(\%)$ & Air Kelapa (\%) & $\begin{array}{c}\text { Pupuk Daun } \\
\text { Majemuk } \\
\text { Growmore }(\mathrm{g} / \mathrm{L})\end{array}$ \\
\hline A & 100 & 0 & 0 \\
B & 50 & 15 & 0 \\
C & 50 & 15 & 1,5 \\
D & 50 & 0 & 1,5 \\
E & 50 & 30 & 1,5 \\
F & 0 & 30 & 3,0 \\
G & 0 & 0 & 3,0 \\
\hline
\end{tabular}

\section{HASIL DAN PEMBAHASAN}

Tabel 2 memperlihatkan bahwa substitusi air kelapa dan pupuk daun majemuk pada media MS menyebabkan perbedaan persentase eksplan yang bertunas. Uji lanjut dengan BNT $5 \%$ menunjukkan bahwa perlakuan E (MS $50 \%$, air kelapa 30 $\%$ dan pupuk daun majemuk $1,5 \mathrm{~g} / \mathrm{L}$ ) menyebabkan rata-rata persentase eksplan bertunas yang tertinggi, yaitu $6,78 \%$ dan berbeda dengan perlakuan lain. Pertumbuhan eksplan yang baik merupakan indikator keberhasilan suatu perbanyakan in vitro. Penambahan bahan subsitutisi seperti air kelapa dan pupuk daun majemuk dengan konsentrasi yang tepat pada media dasar kultur in vitro akan menunjang keberhasilan perbanyakan tanaman anggrek Dendrobium. Media MS merupakan media kultur telah secara luas digunakan (Hartman et al. 1997) dan media MS cocok digunakan untuk perbanyakan tanaman secara in vitro karena memiliki kandungan garam dan nitrat yang tinggi (Taji et al. 1995). Selanjutnya penambahan air kelapa pada media kultur sangat membantu dalam menstimulir perkecambahan, mendorong pembelahan sel dan membantu pertumbuhan tunas (Mandang et al. 1997, Mandang 1997).
Tabel 2. Persentase eksplan yang bertunas

\begin{tabular}{ccc}
\hline Perlakuan & $\begin{array}{c}\text { Rata-rata } \\
\text { persentase } \\
\text { eksplan } \\
\text { bertunas }\end{array}$ & $\begin{array}{c}\text { Notasi (BNT } \\
5 \%=1,99)^{*}\end{array}$ \\
\hline $\mathrm{A}$ & 1.58 & $\mathrm{a}$ \\
$\mathrm{C}$ & 2.88 & $\mathrm{ab}$ \\
$\mathrm{B}$ & 3.08 & $\mathrm{ab}$ \\
$\mathrm{G}$ & 4.25 & $\mathrm{~b}$ \\
$\mathrm{D}$ & 4.39 & $\mathrm{~b}$ \\
$\mathrm{~F}$ & 4.71 & $\mathrm{~b}$ \\
$\mathrm{E}$ & 6.78 & $\mathrm{C}$ \\
\hline
\end{tabular}

* Angka yang diikuti oleh huruf yang sama tidak berbeda

Tabel 3. Jumlah tunas

\begin{tabular}{ccc}
\hline Perlakuan & $\begin{array}{c}\text { Rata-rata } \\
\text { jumlah tunas }\end{array}$ & $\begin{array}{c}\text { Notasi (BNT } \\
5 \%=0,19)^{\star}\end{array}$ \\
\hline A & 0.77 & a \\
C & 0.85 & ab \\
B & 0.88 & ab \\
D & 0.94 & ab \\
G & 0.98 & b \\
F & 0.99 & b \\
E & 1.26 & c \\
\hline
\end{tabular}

* Angka yang diikuti oleh huruf yang sama tidak berbeda

Perlakuan substitusi air kelapa dan pupuk daun majemuk pada media MS menyebabkan perbedaan pertumbuhan jumlah tunas anggrek Dendrobium (Tabel 3). Perlakuan E (MS $50 \%$, air kelapa $30 \%$ dan pupuk daun majemuk 1,5 $\mathrm{g} / \mathrm{L}$ ) menghasilkan rata-rata jumlah tunas terbanyak, yaitu 
1,26. Hasil penelitian ini sesuai dengan penelitian Mandang et al. (1997a dan 1997b) dan Matatula (2003) bahwa air kelapa yang disubstitusi pada media kultur akan meningkatkan pembentukan tunas tanaman krisan dan anggrek. Pemberian air kelapa dapat mendorong pertumbuhan planlet Dendrobium Sonia deep pink (Widiastoety et al. 1997). terhadap penggunaan air kelapa $20 \%$ baik bagi pertumbuhan tunas Dendrobium spp. (Parera 1997). Penambahan air kelapa pada media kultur jaringan dapat memperbaiki pertumbuhan tunas, mendorong pertumbuhan kalus dan morfogenesis (Watimena, Mandang dan Purwito 1990) dan penambahan pupuk daun dalam media MS akan sangat baik untuk masa pertumbuhan vegetatif (Iswanto 2010).

Perlakuan substitusi air kelapa dan pupuk daun majemuk pada media MS tidak berpengaruh terhadap pertumbuhan jumlah daun anggrek Dendrobium (Tabel 4). Pengamatan visual menunjukkan jumlah daun pada seluruh botol pengamatan sangat sedikit (rata-rata tertinggi 1,06) dan adanya kontaminasi pada kultur.

Tabel 4. Jumlah daun

Perlakuan Rata-rata jumlah daun

\begin{tabular}{cl}
\hline A & 0.96 \\
$B$ & 0.96 \\
C & 1.04 \\
$D$ & 1.06 \\
E & 1.06 \\
$F$ & 0.94 \\
$G$ & 1.01 \\
\hline
\end{tabular}

Hanya perlakuan E (MS $50 \%$, air kelapa $30 \%$ dan pupuk daun majemuk $1,5 \mathrm{~g} / \mathrm{L}$ ) yang berpengaruh terhadap tinggi tanaman sebesar 1,20 cm (Tabel 5). Hasil ini sesuai penelitian Mandang (1993) yang menyatakan bahwa penambahan air kelapa sampai $40 \%$ dapat meningkatkan tinggi tanaman dan jumlah tunas tanaman krisan. Air kelapa mengandung zat-zat aktif untuk perkembangan embrio seperti sitokinin yang berperan dalam pembelahan sel tanaman terutama mempengaruhi metabolism asam nukleat dan sintesa protein yang nantinya akan berpengaruh terhadap pembelahan sel dan diferensiasi tanaman (Watimena 1988).

Tabel 5. Tinggi Tanaman

\begin{tabular}{ccc}
\hline Perlakuan & $\begin{array}{c}\text { Rata-rata } \\
\text { Tinggi } \\
\text { Tanaman }\end{array}$ & $\begin{array}{c}\text { Notasi (BNT } \\
5 \%=0,10)^{\star}\end{array}$ \\
\hline F & 0.99 & $\mathrm{a}$ \\
$\mathrm{G}$ & 1.00 & $\mathrm{a}$ \\
$\mathrm{C}$ & 1.01 & $\mathrm{a}$ \\
$\mathrm{A}$ & 1.01 & $\mathrm{a}$ \\
$\mathrm{B}$ & 1.03 & $\mathrm{a}$ \\
$\mathrm{D}$ & 1.05 & $\mathrm{a}$ \\
$\mathrm{E}$ & 1.20 & $\mathrm{~b}$ \\
\hline
\end{tabular}

* Angka yang diikuti oleh huruf yang sama tidak berbeda

Perlakuan substitusi air kelapa dan pupuk daun majemuk pada media MS tidak mempengaruhi jumlah akar anggrek Dendrobium (Tabel 6). Jumlah akar yang terbentuk selama pengamatan relatif sedikit dan hampir sama untuk semua perlakuan Minimnya jumlah akar terbentuk dapat disebabkan oleh adanya sejumlah ulangan yang terkontaminasi dan data pengamatan tidak diperoleh.

\section{KESIMPULAN}

Hasil penelitian menunjukkan substitusi media MS $50 \%$, air kelapa $30 \%$ dan pupuk daun majemuk (Growmore ${ }^{\circledR}$ ) 1,5 g/L menghasilkan rata-rata persentase eksplan yang bertunas sebesar $6,78 \%$; jumlah tunas sebesar 1,26 dan tinggi tanaman sebesar $1,20 \mathrm{~cm}$. 
Tabel 6. Jumlah Akar

\begin{tabular}{cc}
\multicolumn{2}{c}{ Perlakuan Rata-rata Jumlah Akar } \\
\hline A & 0.79 \\
B & 0.85 \\
C & 0.85 \\
D & 0.99 \\
E & 1.02 \\
F & 0.93 \\
G & 0.91 \\
\hline
\end{tabular}

\section{DAFTAR PUSTAKA}

Gunawan LW (1987) Teknik kultur jaringan. Laboratorium Kultur Jaringan Tanaman. Pusat Antar Universitas Bioteknologi IPB, Bogor

Hartman HT, Koster DE, Geneve RL (1997) Plant propagation: principles and practices. 6 th Edition. Prentice Hall, Inc. Simon and Schester. New Jersey

Iswanto H (2010) Petunjuk praktis merawat anggrek. Penerbit PT Agromedia Pustaka. Jakarta

Mandang JP (1993) Peranan air kelapa dalam kultur jaringan tanaman krisan. Disertasi. Institut Pertanian Bogor (1995) Air kelapa sebagai bahan substitusi media MS pada kultur jaringan krisan. Eugenia 1(1):1-11 , Tilaar W, Sumampouw DMF, Suhari (1997a) Pertumbuhan krisan yang mengalami vitrifikasi pada media MS yang sebagian disubstitusi dengan air kelapa. Eugenia 3(2): 52-58

Rondonuwu-L S, Mait M (1997b) Pengaruh air kelapa dan sukrosa terhadap pertumbuhan protocorm anggrek Dendrobium sp. in vitro. Eugenia 3(3):114-119

Parera DjF (1997) Pengaruh tingkat konsentrasi air kelapa terhadap pertumbuhan dan perbanyakan tanaman anggrek Dendrobium spp melalui teknik kultur jaringan. Jurnal IImu Pengetahuan dan Teknologi 2

Taji AM, Dodd WA, Williams RR (1995) Plant tissue culture practice. Armidale. University of $\mathrm{New}$ England

Watimena GA, Mandang J, Purwito A (1990) Pemanfaatan air kelapa muda pada kultur jaringan tanaman. Seminar Nasional II Agrokimia. IPB. Bogor 